\title{
Identification and Prioritization of Environmental Criteria of Sustainable Outsourcing Model in Fajr Jam Gas Refining Company with Analytic Hierarchy Process Method
}

\author{
K. Gholamian ${ }^{1}$, H. Vakilifard ${ }^{2}$, G. Talebnia², R. Hejazi ${ }^{3}$ \\ ${ }^{1}$ Department of Management, Kish International Branch, Islamic Azad University, Kish Island, Iran \\ 2 Department of Management, Tehran Sciences and Researches Azad University, Tehran, Iran \\ ${ }^{3}$ Department of Accounting, Khatam University, Tehran, Iran
}

\section{$P A P E R \quad I N F O$}

Paper history:

Received 06 August 2019

Accepted in revised form 16 September 2019

\section{Keywords:}

Analytic Hierarchy Process

Environmental Criteria

Outsourcing

Sustainability

\section{$A \quad B \quad S T R A C T$}

The purpose of this paper is to identify and prioritize environmental criteria of sustainable outsourcing model in Fajr Jam Gas refining company with hierarchical analysis procedure method. In order to identify environmental criteria, the identified strategic goals of the model are categorized in the most four aspects of the balanced scorecard and three dimensions of economic, social and environmental sustainability. to determine the importance of each environmental criteria in terms of four groups of experts (members of the outsourcing committee, managers, supervisors and experts in the company) are reported using Analytic Hierarchy Process (AHP) method and the results of research are reported through EXPERT CHOICE software. The findings indicated that in order to design sustainable outsourcing model using a balanced scorecard, seven strategic objectives in environmental dimension had to be considered two objectives in learning and growth aspect, two objectives in internal business processes aspect, two objectives in customer satisfaction aspect and a strategic environmental objective in financial performance aspect were identified. Finally, using a paired comparisons questionnaire, the importance of each strategic objective was calculated and prioritized.

\section{INTRODUCTION}

From the beginning of the industrial revolution era, humans and governments attempted to use the fossil energies in order to get their economic growth. The economic growth is along with the enormous use of the materials and energy and considerable damages to the environment [1]. Thus, the environmental risk caused by the economic activities has been changed into a problem for countries, so that protecting the environment and avoiding it is considered as one of the main challenges in front of the world community. Therefore, it is required to give a priority for the environmental considerations over the human economic activities. In this respect, many studies have been provided about the relationship between the economic growth and development and the environment. One of the studies which has excessively been considered is the sustainable growth and development indicators. However, the sustainability measurement as an efficient tool for accessing the sustainable development and the economic, social, environmental and human life improvement was always implicated in the complexities of the human life. This complexity is caused by the interaction of the elements of the study with each other and with the environment [2]. On the other hand, the complexity of the business environment, a competition between the manufacturers, the resource constraint and many other factors are the reason that the manufacturing organizations try to utilize the optimal processes and decisions in order to guarantee the glory survival of the organization [3]. One of the tools which provides the free access to any sources presented in the market is the outsourcing, because most of the companies attempt to utilize all the innovations of the science, techniques and technology for obtaining an eligible and competitive product which satisfies the consumer [4]. Hence, most of the companies prefer to outsource their non-core businesses to other companies in order to diminish the costs and enlarge the efficiency [5] to obtain the economic efficiency. In Iran, the outsourcing topic has been gravely proposed for a long time. Studying the development plans of the country and especially the fourth and fifth development plans were included in clause B, article 5 of the executive by law [6]. Considering the governmental macro policies and goals and the developments in front of the organization, "privatization and minimization of the public sector, the civil service act, the village 44 constitution and 
globalization", the outsourcing of the organization processes and changing in this direction are in accordance with the long-term policies, the strategy and goals of the organization [7]. The governmental organizations are supposed to move from the empty organizations to the agile organizations in order to realize their goals and missions. Based on the village 44, one of the fundamental policies of the governmental organizations in the agility direction is to focus on the core missions and outsource the technologies and activities utilizing the research and industrial capacities of the country [8].

Most of the companies use the outsourcing in order to progress their business goals, because only the use of this approach can help them to respond to the variations obtained with the competitive and economic pressures of the market [9]. On the other hand, the relationship between the economic growth and the environment has a long history that starts with the studies related to the growth and sustainability constraints since 1970s. Throughout this decade, the economic attention of the environment were focused on the economic growth that except the labor and capital factors, the natural resources also followed the production and its major goal was the optimum path of the economic growth by assuming that the storage of the non-renewable and renewable resources are constant [10]. Consequently, the outsourcing strategy can be useful when it is in the sustainable growth and development direction. The sustainable development is the unification of all the economic, social and environmental goals for maximizing the welfare of the current human without damaging the capabilities of the future generation for obtaining the requirements [11]. For this reason, the sustainable outsourcing concept were mentioned and analyzed in order to sustain the assigned processes in the outsourcing strategy. Therefore, the main problem of this research is the environmental dimension of the sustainable outsourcing model, because the environmental degradation in the recent decades, specifically in the field of the oil and gas manufacturing companies has an important role in the air pollution of its encircling environment. Contemplating the mentioned interpretations, the main questions of this research are that, what are the main criteria of the environmental dimension of the sustainable outsourcing model and how much important are these criteria? Therefore, the main purpose of this research is to recognize and understand the importance rate of the environmental criteria of the sustainable outsourcing model in Fajr-e-Jam gas refinery using the analytical hierarchy process method.

Before designing the indicators and the environmental criteria, we will consider the sustainability topic at a level higher than that, because the environmental dimension is one of the dimensions of the sustainability concept. These days, the sustainability concept is very important and it has been educated in all the theoretical fields and it has been converted into a forceful tool for the public policy-making and communication in presenting the information in the countries and the executive organizations in some fields like enhancing the environmental, social, economic and technological conditions [12]. The World Commission on Environment and Development that used this term with the development for the first time and defined the sustainable development as a development which supplies the requirements of the present generation without making problems in the capability of the future generations in fulfilling their requirements [11]. Based on the diverse definitions of the authors, the sustainability management was defined as the adjustment, implementation and assessment of the environmental and social-economic actions and decisions related to the sustainability [13].

The relationship between the environment and the economic growth can be divided into three general categories from the thematic aspect: first, the studies which concentrate on the economic growth and the environmental pollution and meticulously test the environmental Kuznets curve hypotheses. The hypotheses of this curve represent that a one-way causality is existed from the income to the pollution diffusion. The second category of the studies concentrates on the relationship between the economic growth and the energy consumption, because the pollutants diffusions are prevalently expanded by the fossil fuels; thus, the energy consumption has been utilized as an indicator of the pollution diffusion. The third category of the studies among the economic growth and the environmental pollution concentrates on the relationship between the economic growth, the energy consumption and the pollution diffusion [14].

One of the tools which analyzes the relationship between the environmental criteria and the economic criteria is the environmental Kuznets curve. This curve is a complex and forceful tool in order to research the economic relationship and the environmental degradation. Generally, the experimental studies on the environmental Kuznets curve approve the existence of the inverted U-shaped relationship between the pollution and the per capita income [10].

The strategy model of this research is based on the balanced scorecard (BSC). In 1990s, the balanced scorecard model was presented as a modern performance evaluation method and then, as a tool to help the realization of the strategy, by Robert Kaplan who is a famous professor at Harvard University and David Norton who is the leading management consultant in America and it was strongly received from the management experts and the organization managers. The balanced scorecard is a performance evaluation framework that gives a complete look at the company 
performance using a set of the financial and non-financial scales [15] and provides us a framework for depicting the strategy in order to create the value.

The goals of the balanced scorecard have been defined in four faces which are connected to each other in a chain of the causal relationships. In the growth and learning face, the way of combining the people, technologies and other related cases of the organizations are described to support the strategy. The improvement in the growth and learning criteria are the leading indicators for the internal processes, customers and the financial performance [16]. The internal processes face identifies the internal processes outlook of the important activities and the indicators which are recognized in the key processes of the company, including the services of the delivery, development, report, innovation and the development of the new products that are considered to enter the new markets or attract the new customers, the product quality, the production time, the percentage of the faulty products, etc. [17]. The customer face empowers the customers of the organizations to evaluate, intend and improve the main measurement criteria of the customers' situations such as the satisfaction, loyalty, maintenance and attracting new customers, etc. and finally, the financial face represents the measurement and analysis of the financial results of an organization performance [16].

For obtaining the significance of each environmental goal in this research, the analytical hierarchy process (AHP), which is one of the most efficient decisionmaking techniques, has been utilized. The analytical hierarchy process was proposed in past decades. This technique is based on the pairwise comparison and gives the possibility of analyzing the diverse scenarios to the managers [18]. Thus, the analytical hierarchy process can present an analytical tool for determining the significance of the recognized factors and help the decision makers find the best method for their own goals and their comprehending of the problem [5].

Based on the provided studies, the main goal of the outsourcing strategy is to access the financial goals, hence most of the economic indicators are intended and on the other hand, the main goal of this research is to recognize the environmental criteria related to the outsourcing model. Correspondingly, the studies presented about the relationship between the economic dimensions and the environmental dimensions has been emphasized. The summary of the provided studies has been represented in Table 1 .

TABLE 1. Studies presented about relationship between economic dimensions and environmental dimensions

\begin{tabular}{ll}
\hline Authors \& research method & Goals or main questions \\
\hline & $\begin{array}{l}\text { The effect of the environmental } \\
\text { degradation on the economic growth }\end{array}$ \\
Ahmadian et al. [10] & $\begin{array}{l}\text { with proofs from 22 developing } \\
\text { countries }\end{array}$
\end{tabular}

Tarazkar et al. [14]

Descriptive method

Yoo and Heshmati [19]

Descriptive method

Mirzaei et al. [20]

Descriptive method

Salatin and Eslamboulchi

[21], Descriptive method

Mohamad-Taghvaee et al. [1]

Descriptive method

Jafari-Samimi et al. [22]

panel data econometric method

Apergis [23] A combination approach of panel and time series methods

Evaluating the economic factors affer on the environmental pollution in Iran during the years 1971 to 2013 with the macro approach

Analyzing the effect of the environmental regulations on the competitiveness of the manufacturing industries

The effect of the shadow economyon the environmental pressures

Examining the effect of the environment quality on the health economics

Analyzing the E3 model (economic growth, environment and energy) in Iran

Examining the relationship of the environmental performance index and the economic growth

Examining the relationship between the per capita index of the $\mathrm{CO} 2$ per capita production and GDP per capita

\section{The most significant findings and research results}

The research results demonstrated that there is a positive and significant relationship between the economic growth and the environmental degradation (environment quality reduction) and it means that an enlargement in the environmental degradation index will enlarge the economic growth [10].

The research findings represented that the effect of the energy consumption variable is placed at a high level of the statistics importance, so that it is expected that by increasing the per capita energy to $10 \%$, the per capita pollution diffusion will increase to $8 \%$ in long term and $6 \%$ in short term. Based on the research results, $80 \%$ of the pollution diffusion is related to the energy section [14]
The results represented that an enlargement in the spent disbursement the innovations rate and then, the competitiveness of the industries [19].

The results represented that the relationship between the shadow economy and the environmental pressure is positive and significant. In order that a $1 \%$ increase in the size of the shadow economy will have a $3.19 \%$ increase in the environmental pressures [20].

The research results demonstrated that the air pollution has a positive and significant effect on the health expenditures [21].

The study results represented that the effect of the energy consumption and the environmental pollution on the economic growth is positive and significant [1].

The results represented that in the developed countries, the economic growth has a negative effect on the environmental performance, in another word, the increase in the economic growth will degrade the environment or reduce the environment quality in the examined time interval [22].

Based on the research results, the U-shaped relationship between the environmental degradation index (pollution) and the per capita income of GDP is represented. His research results demonstrated that the environmental Kuznets indicator credit hypothesis is kept in 12 cases from 15 countries [23]. of the industries for decreasing the pollutants will significantly expand 


\section{MATERIALS AND METHODS}

This research is an exploratory research based on the selection approach of the research theme. Also, this research is a descriptive-survey research based on the design.

The statistical population is the entire gas refineries of Iran that the research has been performed as a case study in Fajr-e-Jam gas refinery complex in the form of designing the sustainable outsourcing model as a research project. The validity evaluation, the inconsistency estimation and also the pairwise comparison in this research were provided by distributing the content validity questionnaire and the pairwise comparison questionnaire between 13 specialists and experts of the company according to Table 2 .

For the content validity, the content validity ratio (CVR) and the content validity index (CVI) have also been utilized. For guaranteeing the reliability, the inconsistency ratio (IR) in the questionnaires based on the pairwise comparison and based on the report from EXPERT CHOICE software in the reliability analysis section of the pairwise questionnaires have been utilized. Because the questions were evaluated based on the content validity questionnaires of 13 experts, the questions that their CVR value was less than 0.54 were ignored. Because they did not have an admissible content validity and the rest of the responses were confirmed. In order to evaluate the content validity index, Waltz \& Bausell method was utilized. The minimum admissible value for each CVI is equal to 0.79 and the CVI of the

TABLE 2. Specifications of the experts in this research

\begin{tabular}{|c|c|c|c|}
\hline Row & $\begin{array}{r}\text { Specifications } \\
\text { Jan }\end{array}$ & $\begin{array}{l}\text { the experts in Fajr-e- } \\
\text { as refinery }\end{array}$ & $\begin{array}{l}\text { Number of } \\
\text { experts }\end{array}$ \\
\hline \multirow{3}{*}{1} & \multirow{3}{*}{$\begin{array}{l}\text { Management } \\
\text { experience }\end{array}$} & More than 20 years & 6 \\
\hline & & More than 10 years & 7 \\
\hline & & Less than 10 years & 0 \\
\hline \multirow{3}{*}{2} & \multirow{3}{*}{$\begin{array}{l}\text { Organizational } \\
\text { ranking }\end{array}$} & $\begin{array}{l}\text { Less than } \\
\text { organizational } \\
\text { ranking } 17\end{array}$ & 2 \\
\hline & & $\begin{array}{l}\text { organizational } \\
\text { ranking } 17\end{array}$ & 4 \\
\hline & & $\begin{array}{l}\text { More than } \\
\text { organizational } \\
\text { ranking } 17\end{array}$ & 6 \\
\hline \multirow{3}{*}{3} & \multirow{3}{*}{ Education } & Bachelor of science & 1 \\
\hline & & Master of science & 10 \\
\hline & & $\begin{array}{l}\text { Higher than master of } \\
\text { science ( } \mathrm{PhD} \text { student) }\end{array}$ & 2 \\
\hline \multirow{3}{*}{4} & \multirow{3}{*}{ Age } & Less than 40 & 2 \\
\hline & & Between 40 to 50 & 9 \\
\hline & & More than 50 & 2 \\
\hline
\end{tabular}

responses less than 0.79 was eliminated. In this research, three methods have been utilized to collect data. The library method was used to recognize the factors which have effects on the outsourcing, the questionnaire tool was utilized to determine the content validity and the pairwise comparison of the strategic goals and the affinity diagram was used to recognize the strategic goals of the research model.

The method was performed in the way that after extracting 152 initial success factors, the content validity questionnaire was distributed among the experts of the company and the content validity ratio and the content validity index were calculated and 114 criteria were confirmed from the validity viewpoint.

\section{RESULTS}

In this stage of research, collecting and examining the required information and data and classifying the success factors into the sustainable dimensions and the balanced scorecard perspectives (114 final criteria), using the affinity diagram, the factors were recognized with the help of the research experts in 26 strategic goals. The strategic goals of environmental dimension and parameters is presented in Table 3 and the sustainable outsourcing strategy model map was designed according to Figure 1 that two strategic environmental goals for the learning and growth face, two strategic environmental goals for the business processes face, two strategic environmental goals for the customer satisfaction face and one strategic environmental goal for the financial performance face were extracted.

After recognizing the strategic goals, the pairwise comparison questionnaire of the balanced scorecard faces and the pairwise comparison of each face goals were distributed among the research experts. The analysis of all the questionnaires were performed in a way that the inconsistency of all the pairwise comparisons of each questionnaire was calculated and the pairwise comparison questionnaires were analyzed utilizing Expert Choice software and since the consistency of all the provided pairwise comparisons was less than 0.1 , all the pairwise comparisons were confirmed.

After creating the model in the program and entering the pairwise comparison matrices, the weights of the criteria were achieved. The prioritization of 4 criteria from the point of the sample people has been represented with the help of Expert Choice software.

Based on the performed comparisons and the obtained weights, in the sub-criteria form related to the balanced scorecard, the "financial performance" dimension has the highest importance. The dimensions of "internal business processes" and "customer satisfaction" are in the next priorities (Figure 2). 
TABLE 3. Criterias, strategic goals and parameters of environmental dimension

\begin{tabular}{|c|c|c|c|}
\hline Balanced Scorecard & Outsourcing Success Criterias & Strategic Goal & Parameter \\
\hline \multirow{2}{*}{$\begin{array}{l}\text { Growth And } \\
\text { Learning }\end{array}$} & Having valid certificates such as ISO 9001, SEI or CMM & $\begin{array}{l}\text { Obtain Appropriate Certification } \\
\text { With Outsourced Activity }\end{array}$ & LEn1 \\
\hline & observance environment health and employee health & $\begin{array}{c}\text { Observing The Principles Of } \\
\text { Environmental Health And Staff } \\
\text { Health }\end{array}$ & LEn2 \\
\hline \multirow[t]{2}{*}{ Internal Processes } & $\begin{array}{c}\text { Complete compliance with supplier safety and security principles } \\
\text { and issues } \\
\text { Preventing air and environmental pollution } \\
\text { Compliance of legal and organizational requirements after post- } \\
\text { contract }\end{array}$ & Environmental Management & PEn1 \\
\hline & $\begin{array}{l}\text { The Health Management of the Environment and the Health of } \\
\text { the Staff }\end{array}$ & Employee Health Management & PEn2 \\
\hline \multirow{2}{*}{$\begin{array}{l}\text { Customer } \\
\text { Satisfaction }\end{array}$} & Environmental Health and Staff Health & Clean And Healthy Environment & CEn1 \\
\hline & Providers' obligations regarding service safety & Product Or Service Safety & CEn2 \\
\hline $\begin{array}{l}\text { Financial } \\
\text { Performance }\end{array}$ & $\begin{array}{l}\text { Supply management and Optimal energy consumption } \\
\text { Resource management and optimal water consumption }\end{array}$ & Green Economy & FEn1 \\
\hline
\end{tabular}

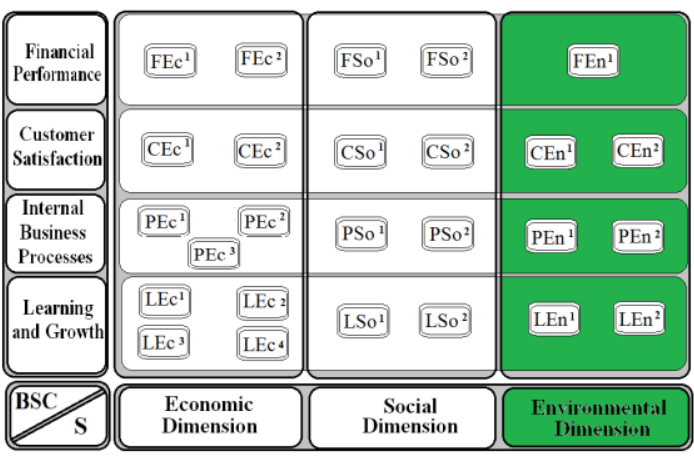

Figure 1. Sustainable outsourcing balanced scorecard map
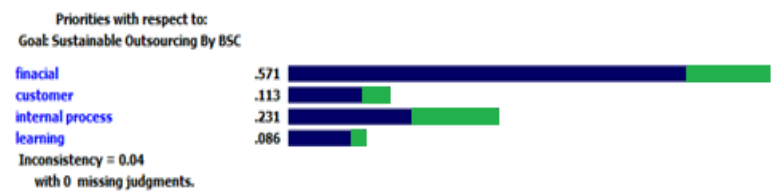

Figure 2. Prioritizing the main criteria importance of the balanced scorecard

Based on the pairwise comparison of the learning and growth face criteria, the importance rate of the environmental criteria "achieving the valid certificates suitable with the outsourced activities" is equal to 0.096 and "observing the principles of the environmental health and the staff health" is equal to 0.113 . The environmental criteria of each face are demonstrated in green. The results shown in Figure 3.

Furthermore, in the internal processes face, the importance rate of the environmental criteria "environment management" is equal to 0.135 and "staff health management" is equal to 0.122 (Figure 4).
Based on the provided comparisons and As shown in Figure 5, the importance rate of the environmental criteria "clean and healthy environment" is equal to 0.159 and "product or service safety" is equal to 0.191 .

As shown in Figure 6, the pairwise comparison of the financial performance face criteria was provided that the importance rate of the environmental criteria "green economy" is equal to 0.129 .
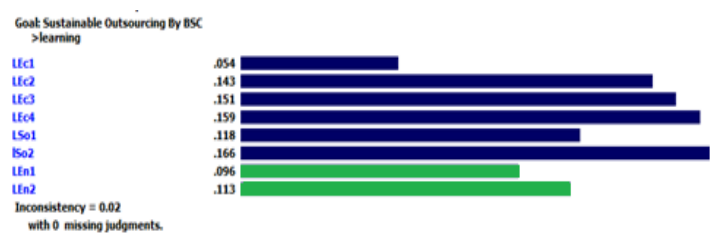

Figure 3. Prioritizing the importance of learning and growth face criteria
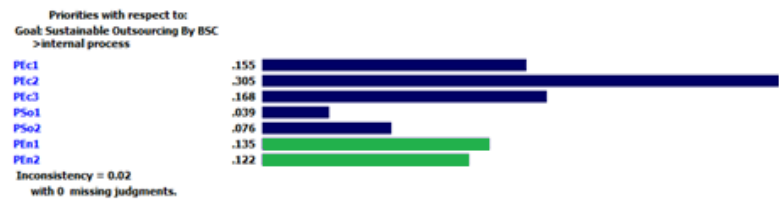

Figure 4. Prioritizing the importance of internal business processes face criteria
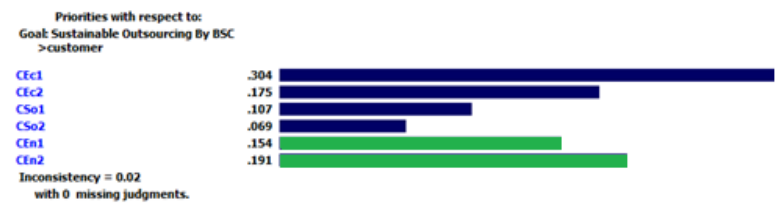

Figure 5. Prioritizing the importance of customer satisfaction face criteria 


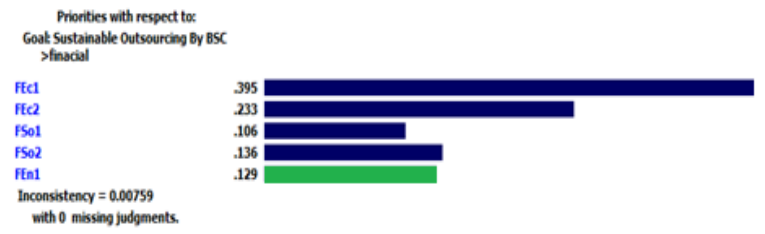

Figure 6. Prioritizing the importance of the financial performance face criteria

\section{DISCUSSION}

Based on the theoretical foundations of the research, the environmental Kuznets curve represents the relationship between the economic growth and the environmental pollution and on the other hand, based on the research results, dependency between the environmental factors and the economic factors in the sustainable outsourcing model was obvious. Thus, Kuznets curve as one of the measurement indices of finding the relationship rate between the economic and environmental dimensions criteria in the sustainable outsourcing model can be examined.

The research findings demonstrate that for the sustainability, it is supposed to consider the strategic goals of the research model with three economic, social and environmental dimensions that this result confirms the theoretical foundations reported in literature [13].

Also, the results of this research confirm the researches of Ahmadian et al. [10] and Tarazkar et al. [14] in the section of the relationship between the air pollution and the energy consumption, Yoo and Heshmati [19] and Salatin and Eslamboulchi [21] in the section of the relationship between the environmental pollution and the staff health, but the main goal of the research model is to decrease the environmental effects, notwithstanding the economic activities. In another word, this research attempts to minimize the positive and significant relationships between the environmental pollution and the economic growth presented by JafariSamimi et al. [22], Mohamad-Taghvaee et al. [1] and Apergis [23]. i.e. performing the sustainable economic activities by considering the environmental factors in all the processes and economic activities of companies. This research can manifestly represent the vital role of the environmental factors in the economic activities at the gas refineries.

\section{CONCLUSION}

The present study has been provided with the purpose of recognizing and prioritizing the environmental criteria of the sustainable outsourcing model in Fajr-e-Jam gas refinery using the analytical hierarchy process. The findings of the research represented that for providing the sustainable outsourcing process using the balanced scorecard, the economic, social and environmental sustainability must be contemplated in each face of the balanced scorecard that with the help of this model, it is possible to have the sustainable learning and growth, the sustainable internal business processes, the sustainable customer satisfaction face and the sustainable financial performance face. For the sustainability of the environmental dimension, in the growth and learning face, two strategic goals "achieving the valid certificates suitable with the outsourced activities" with the importance rate of 0.113 and "observing the principles of the environmental health and the staff health" with the importance rate of 0.096 , in the internal processes face also two goals "environment management" with the importance rate of 0.135 and "staff health management" with the importance rate of 0.122 and in the customer face, two goals "clean and healthy environment" with the importance rate of 0.154 and "product or service safety" with the importance rate of 0.191 and in the financial face of the balanced scorecard, one strategic goal "green economy" with the importance rate of 0.129 were recognized. Also, the significance of the environmental dimension in the growth and learning face is equal to 0.209 , the significance of the environmental dimension in the internal processes face is equal to 0.257 , the importance of the environmental dimension in the customer face is equal to 0.345 and the importance of the environmental dimension in the financial face is equal to 0.129 .

\section{REFERENCES}

1. Mohamad Taghvaee, V., Khodaparast Shirazi, J., Boutabba, M. A., and Seifi Aloo, A., 2017, Economic Growth and Renewable Energy in Iran, Iranian Economic Review, 21(4), pp.789-808.

2. Chen, R.S. and Tsai, C.M., 2017, Development of an evaluation system for sustaining reservoir functions - a case study of Shiwen Reservoir in Taiwan, Sustainability, 9(8), p.1387-1404.

3. Ramkumar, N., Subramanian, P. and Rajmohan, M., 2009, A multicriteria decision making model for outsourcing inbound logistics of an automotive industry using the AHP and TOPSIS, International Journal of Enterprise Network Management, 3(3), pp.223-245.

4. Tayauova, G., 2012, Advantages and disadvantages of outsourcing: analysis of outsourcing practices of Kazakhstan banks, Procedia-Social and Behavioral Sciences, 41, pp.188-195.

5. De Felice, F., Petrillo, A. and Autorino, C., 2015, Development of a framework for sustainable outsourcing: Analytic Balanced Scorecard Method (A-BSC), Sustainability, 7(7), pp.8399-8419.

6. Mahdavi Mazdeh, M. and Lotfollah Hamedani, M.R., 2012, A new outsourcing framework: A case study of educational institution activities, Management Science Letters, 2(3), pp.1005-1010.

7. Alamtabriz, A., and Shayesteh, R., 2011, Evaluation and Prioritization of Tax Collection Process Outsourcing in the Iranian 
National Tax Administration by Employing the Fuzzy Topsis Approach, Tax Journal, 10(58), pp.189-220. (In Persian)

8. Karimi Govareshki, M.H., Hosseini, S.J. and Taghinejad, R., 2017 Use of knowledge maps in collaborative networks management (case study: SSFR company), International Journal of Computer Science and Network Security, 17(9), pp.21-28.

9. L Cheshmberah, M. and Mortazavi, M., 2008. Effective outsourcing management, Tehran: Institute Mehraban Book.

10. Ahmadian, M., Abdoli, G., Jebel Ameli, F., Shabankhah, M., and Khorasani, S.A., 2017, Effect of Environment Degradation on Economic Growth (Evidence from 32 Developing Countries), Journal of Economic Growth and Development Research, 7(27), pp.17-28. (In Persian)

11. Azadnia, M., Zahedi, S. and Pourabedy, M.R., 2017, Analysis of the impact of ICT on sustainable development using sustainability indicators, International Journal of Computer Applications, 169(6), pp.975-8887.

12. Singh, R.K., Murty, H.R., Gupta, S.K. and Dikshit, A.K., 2009, An overview of sustainability assessment methodologies, Ecological Indicators, 9(2), pp.189-212

13. Opresnik, D. and Taisch, M., 2015, The conceptualization of sustainability in operations management, Procedia CIRP, 29 , pp.532-537.

14. Tarazkar, M.H., Kargar Dehbidi, N., and Bakhshoodeh, M., 2018 , The Effects of Economic Development and Urbanization on Pollution Emissions in Iran, Journal of Agricultural Economics Research, 10(2), pp.155-174. (In Persian)

15. Cardinaels, E. and van Veen-Dirks, P.M., 2010, Financial versus non-financial information: The impact of information organization and presentation in a Balanced Scorecard, Accounting, Organizations and Society, 35(6), pp.565-578.
16. Kaplan, R.S., Kaplan, R.E., Norton, D.P., Norton, D.P. and Davenport, T.H., 2004, Strategy maps: Converting intangible assets into tangible outcomes. Harvard Business Press.

17. Bețianu, L. and Briciu, S., 2011, Balanced Scorecard-Sustainable Development Tool, Alexandru Ioan Cuza University, Iasi, Romania, pp.19-27.

18. Ghodsipour, S.H., 2000. Analytical Hierarchy Process (AHP), 2nd edition, Amirkabir University of Technology (AUT) Press Center, Tehran, Iran.

19. Yoo, S. and Heshmati, A., 2019, The Effects of Environmental Regulations on the Manufacturing Industry's Performance: A Comparison of Green and Non-Green Sectors in Korea, Energies, 12(12), pp.2296-2309.

20. Mirzaei, A., Esfanjari-Kenari, R.; Mahmoudi, and A., Shabanzadeh, M., (2016), Shadow Economy and its Role in Control of Environmental Damages of MENA Countries, Quarterly Journal of Economic Growth and Development Research, 6(24), pp. 107-118. (In Persian)

21. Salatin, P., and Eslambolchi, S., 2016, Examining Effect of Air Pollution on Health Expenditure in Selected Countries, Journal of Environmental Science and Technology, 18(1), pp.107-121. (In Persian)

22. Jafari-Samimi, A., Ahmadpour, S.M., Moghaddasi, R. and Azizi, K., 2011, Environmental performance and economic growth: new evidence from the Oic countries, Advances in Environmental Biology, 5(4), pp.655-666.

23. Apergis, N., 2016, Environmental Kuznets curves: New evidence on both panel and country-level $\mathrm{CO}_{2}$ emissions, Energy Economics, 54, pp.263-271.

مسئله اصلى اين يزوهش تخريب محيط زيست در دهاهاى اخير بخصوص در حوزه شركتهاى توليدى نفت و كاز كه نقش زيادى در آلودگى هواى محيط

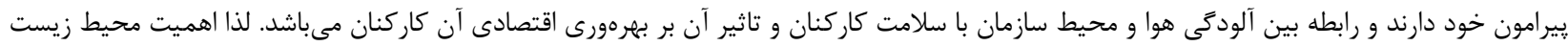

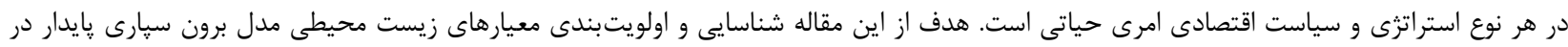

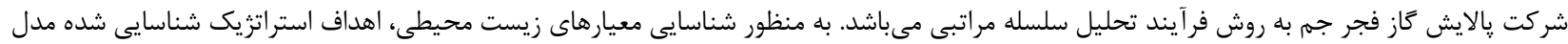

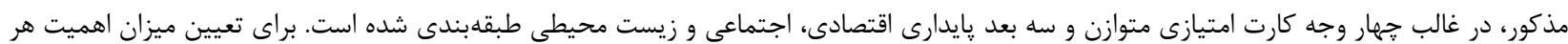

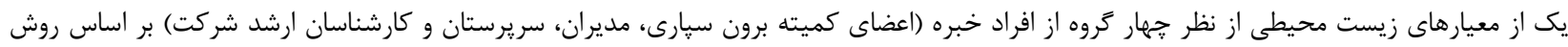

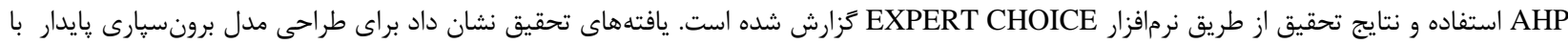

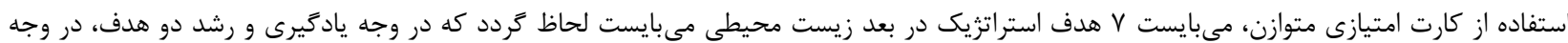

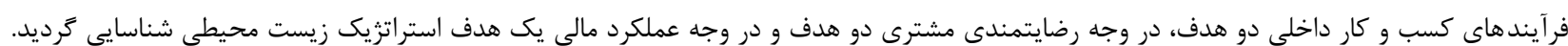

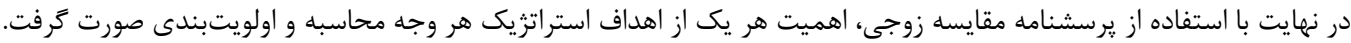

